\title{
Review on Problems, Prospects and Economic Contribution of Wildlife Management and Ecotourism in Ethiopia
}

Malede Birhan* and Girma Gebreyes

University of Gondar, Faculty of Veterinary Medicine, Department of Animal Production and Extension, Gondar-196, Ethiopia

*Corresponding author: Malede Birhan, University of Gondar, Faculty of Veterinary Medicine, Department of Animal Production and Extension, Gondar-196, Ethiopia, Tel: 251 581141232; E-mail: birhan1975@yahoo.com

Rec date: Aug 13, 2015; Acc date: Sep 10, 2015; Pub date: Sep 12, 2015

Copyright: ( $) 2015$ Birhan M, et al. This is an open-access article distributed under the terms of the Creative Commons Attribution License, which permits unrestricted use, distribution, and reproduction in any medium, provided the original author and source are credited.

\begin{abstract}
Ethiopia contains one-fourth of Africa's wildlife and is comprised of 277 terrestrial mammals, 861 birds, 201 reptiles, 65 species of amphibians, 150 freshwater fish, and over 1,225 arthropods with a high rate of endemism, but It's Wildlife populations and their management are constrained by different factors. Habitat destruction, fragmentation, poaching, and lack of clear national and international policies, lack of commitment from government officials, scarcity of funds, expansion of large scale agriculture, illegal exploitation of natural resources, and lack of skilled staff are the main ones. In addition to these, Ethiopia's Ecotourism potential is huge and unmatched but the sector is in its infancy stage due to lacks of effective and sound institutional framework and legal bases for ecotourism development in related to the less emphasis and recognition given to ecotourism and also lack of cohesiveness, integrity and cooperation among the stakeholder. Most of the national parks and protected areas of the country are under pressure from the surrounding communities in search of cultivable land, grazing land, or wood for different purposes. These seminar papers give a highlight, not only on the problems of wildlife management and ecotourism in Ethiopia, but also the economic contribution and prospects of wildlife management and ecotourism in Ethiopia. It also give an over view on ecology, ecosystem and biodiversity in the area.
\end{abstract}

Keywords: Prospect; Wildlife; Ecotourism; Economic value; Ethiopia

\section{Introduction}

Ethiopia, officially the Federal Democratic Republic of Ethiopia, is a country situated in the Horn of Africa that has been landlocked since the independence of its northern neighbor Eritrea in 1993. Apart from Eritrea to the north, Ethiopia is bordered by Sudan to the west, Kenya to the south, Djibouti to the northeast, and Somalia to the east [1]. It is one of the few countries in the world that possesses a unique and characteristic fauna and flora with a high level of endemic species (World Conservation Monitoring Center) [2]. Ethiopia's present wildlife potential consists of 277 terrestrial Mammals, over 861 bird species, 201 species of reptiles, 63 species of amphibians and 150 Species of fish. Among these, 31 mammals are believed to be endemic and out of these 20 are considered highland forms. Among birds, Ethiopia owns about 32 endemic species, some of which are shared with Eritrea [3].

Usually, these expansions are at the expense of wildlife resources leading to the loss of both flora and fauna together with their habitats. In an effort to conserve natural resources, Ethiopia has established many protected areas. National Parks and Sanctuaries, which are referred to as principal conservation areas, cover only approximately $2.9 \%$ of the country's surface area [4]. Besides, the understanding and the agreement with the principles of nature preservation and durability for a growing portion of the population took part in the evolution of the term "ecotourism." Ecotourism is often considered as a form of tourism with "a strong motivation." It offers nations the opportunity to get the most out of their natural attractions and to gain all the economic benefits without losing their rich biological resources. As with many developing countries, wildlife management and Ecotourism in Ethiopia are constrained by different factors [5].

\section{Objectives of this paper}

To assess the problems and prospects of wildlife management and ecotourism in Ethiopia.

To evaluate the biodiversity and economic contribution of wildlife and ecotourism in the study area.

\section{Ecology and Ecosystem Condition of the Country}

The word 'Ecology' was coined from the Greek world 'oikos' meaning 'house' or 'a place to live' to designate the study of organisms in their natural homes and the the term "logy" is to mean study. Specially, it means the study of interactions of organisms with one another and with the physical and chemical environment [6]. They evolve and adapt in response to the environment in which they live. An ecosystem is a community of living organisms (plants, animals and microbes) in conjunction with the nonliving components of their environment (things like air, water and mineral soil), interacting as a system. Biotic and a biotic component are regarded as linked together through nutrient cycles and energy flows [7]. Ethiopia is endowed with diverse ecosystems in which diverse flora and fauna as well as microbial resources are found. The major ecosystems include: Afroalpine and subafroalpine, Montanan dry forest and scrub, Montanan moist forest, Acacia-Comiphora woodland, CombretumTerminalia woodland, Lowland humid forest, aquatic, wetland, montane grassland, and Desert and semidesert ecosystems [8]. 


\section{Wildlife Habitats and Biodiversity}

Diversity can be defined as the variability among living organisms from all sources and the ecological systems of which they are apart; this includes compositional, structural and functional diversity at regional-landscape, ecosystem-community, species-population or genetic level [9]. Biological diversity or "biodiversity" has been defined by the Convention on Biological Diversity (CBD) as "the variability among living organisms from all sources including Inter alia, terrestrial, marine and other aquatic ecosystems and the ecological complexes of which they are part; this includes diversity within species, between species, and of Ecosystems. This variety provides the building blocks to adapt to changing environmental conditions in the future [10]. The wildlife species is only a small component of biological diversity (biodiversity), which refers to the variety of all living organisms at the genetic, species and ecosystem levels [11].

Wildlife traditionally refers to non-domesticated animal species, but has come to include all plants, fungi, and other organisms which grow or live wild in an area without being introduced by humans [12]. Although it may be inappropriate to restrict wildlife to a few kinds of organisms common usage, public perceptions, funding allocations, and history have resulted in a practical definition of wildlife as undomesticated free-ranging vertebrates. The definition of wildlife is left as essentially undomesticated, free-ranging terrestrial vertebrates (reptiles, amphibians, birds, and mammals) [13]. These diverse species of wildlife are protected and managed in different conservation areas (Ethiopia Wildlife Conservation Authority [14]. The variety of ecosystems and diverse topography of Ethiopia provide a wide spectrum of habitat type for many fauna and flora species. Ethiopia has $70 \%$ of all the afro-tropical lands above $2,000 \mathrm{~m}$ and $80 \%$ of all the lands above 3,000 $\mathrm{m}$ [15]. The Bale Mountains National Park (BMNP) in the southeast has some of the largest areas of continuous and Afromountain forest habitats in Africa followed by the fragmented Afroalpine ecosystem in the north western highland [16]. Bale Mountains National Park covers about $1990 \mathrm{~km} 2$ followed by Arsi Mountain which cover about $1000 \mathrm{~km} 2$. The coverage of others Afro-alpine areas which found in northern Ethiopia are: Simien Mountains National Park (SMNP) (960 km2), South Wollo $(1220 \mathrm{~km} 2)$ and the fragmented north Wollo areas together cover $1150 \mathrm{~km} 2$ [16]. Those Afro-alpine habitats are the home of endemic flagship species, such as the Ethiopian wolf (Canis simensis), Gelada baboon (Theropithecus gelada), Walia Ibex (Capra walia) and the Mountain Nyala (Tragelaphus buxtoni), together with other remarkable flora and bird species. Those species are completely or partially restricted to only these habitats [17]. The range of habitats of Afro-tropical Highland Biome can be characterized by at least three types of wildlife habitat. These are the Upland Humid Forest Vegetation/Habitat, the Upland Rain Forest Vegetation/Habitat and the Riparian Habitat and Wetland.

In and Around Abijata-Shala Lakes National Park (ASLNP); there are about 300 species of birds residing in ASLNP and ASLNP is also the home for diversified and populated wildlife species; among these mammals such as Grants Gazelle, warthogs were observed around headquarter of the park and at distant areas from the park headquarter [18]. Most bird watching itineraries are in the south of the country an itinerary in search of all of Ethiopia's endemic birds would take in Debre Libanos, north of Addis Ababa, the Jemma River valley, the escarpment north west of Addis Ababa, around Debre Berhan and Ankober and the descent to Melka Jedbu, the Awash National Park, the Rift Valley Lakes, Wondo Genet, Bale and the road south through the Harenna forest to Negele, the area near the border with Somalia near
Bogol Manyo, west from there to Yabello, Konso and Fejej and Nech Sar National Park [19].

\section{Wildlife Management and Ecotourism}

The Co-operative Research Centre (CRC) for Sustainable Tourism (2001) [20], describes that, wildlife tourism as "tourism that involves encounters with non-domesticated animals either in their natural environment or in captivity. Wildlife tourism developed rapidly grown after Second World War in the form of wildlife viewing in national parks and game refuge on government or state-owned land and many tourists prefer to see and interact with wild species in their habitats and experience a much more intimate closeness to authentic habitats. What really sets Ethiopia apart is that it is home to more than 20 endemic species, the beautiful Bale mountains host 16 of these endemics and the Awash National Park is home to 6 of these endemics and birds are the backbone of the Ethiopian tourism that attracts a lot of tourist's today [21]. Wildlife management is the process of keeping certain wildlife populations, including endangered species, at desirable levels on the basis of scientific, technical and traditional knowledge. It can be also defined as art and science of managing wildlife populations and their habitats with the participation of stakeholders [22]. The Protected areas of Ethiopia are closely hemmed-in and utilized by the agrarian and pastoralist communities. There are 19 National Parks, 3 Wildlife Sanctuaries, 2 Wildlife Reserves, 19 Controlled Hunting Areas, and 10 Open Hunting Areas. Yet, only 2 National Parks-the Simian and Gambella are gazette notified, other protected areas including the game reserves, sanctuaries, national forest priority areas are not gazette [18].

\section{Economic Contribution of Wildlife and Ecotourism}

Wildlife has the potential to significantly contribute to both local and national economies. Wildlife in eastern Africa have a major aesthetic value to tourists who want to see and appreciate wild game species especially if this can be done within their natural environment/ ecosystem or some approximation if not establishing zoo is equally relevant. Wildlife provides a variety of goods such as hides, skins, ivory, horns, meat traditional medicine and subsistence hunting $1 \%$ in Ethiopia. The non-consumptive use includes eco-tourism development that the country has still great potential, if facilities for suitable accommodation and other services are available, and properly marketed [23].

\section{Prospects and Problems of wildlife in Ethiopia}

As with many developing countries, wildlife management and conservation activities in Ethiopia are constrained by limited personnel, equipment, and software, funding and training [24]. Constraints are classified into four categories which are; political, economic, social and biological constraints. Social constraints included negative perceptions of wild life and, lack of capacity to achieve conservation, lack of environmental awareness, rising human populations, and social changes leading to subdivision of land and consequent habitat fragmentation [14]. Habitat destruction, fragmentation, poaching, and lack of proper management are among the various problems that are decimating or threatening the quality and quantity of wild biodiversities in Ethiopia [25]. The major components of habitat destruction and disturbance in Ethiopia are settlement in and around the Sanctuary, overstocking livestock, frequent fire and bush encroachment, tree cutting for fuel, sale and 
construction of huts [26]. The conservation of natural resources in National Parks, Sanctuaries and nature reserves has always been entangled in multitude of problems. Among these, lack of clear national and international policies, lack of commitment from government officials, scarcity of funds, expansion of large scale agriculture, illegal exploitation of natural resources, and lack of skilled staff are the main ones [27].

Encroachment from the surrounding communities is currently among the major problems of parks like Semin national park, Awash National park, Bale mountain National Park, Borena-Saynt national park and Nech-sar national park [14]. Park management for long typically period of time in Ethiopia was state centered, Top-down, exclusionary and coercive against local people which relies on "fences and fines" and considered local people as hostile to park resources. Locals living adjacent to protected areas are forced to displace without their consent which is one of the major reasons for mass destruction of parks after the collapse of the Derg regime [28].

In many cases, the absence of adequate survey data to monitor wildlife populations and distributions prevents timely management and conservation decisions that could ultimately save a species or population. This is especially true with rare and endangered species in developing Countries, where wildlife managers have, limited resources and information to formulate effective conservation strategies [24]. To fill those gaps, the new department will offer opportunities in training of appropriate persons through provision of widespread theoretical and practical knowledge and skill in wildlife management [25]. Furthermore, recently a new proclamation has been passed and endorsed by the House of Representatives to restructure with the newly established autonomous institution, the Ethiopian Wildlife Conservation Authority (EWCA) under the Ministry of Tourism and Culture. The new proclamation is made in Addis Ababa on 22nd May 2008 on 14th year no 31, under the Proclamation number of 575/2008 and is designated as Ethiopian Wildlife Development and Conservation Authority (EWDCA). It is believed that the new institutional set up would help the country with clear direction and coherence to implement and develop the wildlife resources effectively with sound management procedures and accountability. Ethiopia has the world's second largest wildlife migration which would be an interest to investors. EWCA has a vision of becoming one of the top five wildlife tourism destinations in Africa by 2020 [29].

\section{Ecotourism}

Tourism comprises the activities of persons traveling to and staying in places outside their usual environment for not more than one consecutive year for leisure, business and other purposes. It could be act as business in rural areas since it does not require year's long vocational training [30]. It is not just the temporary movement of people to destinations outside their normal places. It includes many geographic, economic, environmental, social, cultural and political dimensions [31]. According to the World Tourism Organization, there were 846 million international tourist arrivals in 2006 only, which showed an increase of $5.4 \%$ over the previous year [32]. The tourism potential of Ethiopia is diversified: natural attractions that include some of the highest and lowest places in Africa along with immense wild life including some endemic ones; a very old and well preserved historical traditions with fascinating stelae, churches and castles to witness that, an attractive cultural diversity of about 80 nations and nationalities; and various ceremonies and rituals of the Ethiopian Orthodox Church which open a window on the authentic world of the
Old Testament [33]. The favorable diversity of climate is the other factor what makes Ethiopia to attract tourists. Having Addis Ababa as venue of seat for Africa Organization Unity and United Nation Economic, commission for Africa is also another feature of attractions for Ethiopia [34].

\section{Concepts in Ecotourism}

Ecotourism is a relatively new idea and has emerged in the late 1990's that has dramatically captured the attention of many people from a variety of backgrounds. In a market primarily demanded by the west where 'green' products experienced a boom over the last years, it became a buzzword which sells good and can bring higher revenues for tourism industry. Tour operators offer 'eco-friendly' activities and 'green labeled' companies are universal, whereas coevally explicit guidelines and principles are missing. Thus, the term remains unspecific in tourism industry as well as in research [35]. The International Ecotourism Society defines ecotourism very general as "responsible travel to natural areas that conserves the environment and improves the well-being of local people" [36]. International Union for Conservation of Nature (IUCN) defined it as environmentally responsible travel to natural areas, in order to enjoy and appreciate nature that promote conservation, have a low visitor impact and provide for beneficially active socioeconomic involvement of local people" [37].

\section{Ecotourism Development and Economic Contribution in Ethiopia}

The concept of ecotourism is a new phenomenon to and it is difficult to explain its Significance achievement since the approach of ecotourism is not widely disseminated in Ethiopia. The government of Ethiopia also has recognized development and promotion of ecotourism and provided consultancy services for a number of potential developers of ecotourism sites [38]. Bishangari Eco-Lodge located at Eastern of Langano Lake in Oromia Region and Village Ethiopia located at Afar Region (Bilen) is examples of these private ecotourism developments in Ethiopia [26]. There are some promising community based ecotourism initiatives like Adaba-Dodola, which is financially and technically supported by the German Agency of Technical Cooperation or GTZ (now GIZ) on the northern slopes of the Bali Mountains in Oromia National Regional State and Semien Mountain (a pilot ecotourism project on SMNP) [39]. The Ecotourism Association of Ethiopia (EAE), which was founded in 2003 by committed organizations of the private sector, is basically formed to promote the principles ecotourism and eco-efficient initiatives in order to address the challenges faced by the tourism sector [30].

At some ecotourism destinations, residents benefit from revenue sharing programs that either provides cash payments or, more commonly, funding for community projects such as wells or schools [40]. It also provides new markets for locally produced goods, increased government revenues through fees and taxes paid by visitors, and serves as insurance for the protected areas from being converted to other land use types [41]. Tourism is an excellent means for transferring income from wealthy nations and persons to the poorer sections of society. Ecotourism is especially effective in this transfer since travelers often vent in to remote, economically disadvantaged regions [42]. 


\section{Constraints and Prospects of Wildlife Management and Ecotourism}

Ethiopia lacks effective and sound institutional framework and legal bases for ecotourism development in related to the less emphasis and recognition given to ecotourism and also lack of cohesiveness, integrity and cooperation among the stakeholders like government, local communities and NGOs are serious problems stagnated ecotourism Development [43]. Intergovernmental Authority on Development (IGAD) member states comprising of Djibouti, Eritrea, Ethiopia, Kenya, Somalia, Sudan and Uganda have supported tourism development and ecotourism is slowly but steadily developing in most member countries and it states that weak policy, legal and regulatory framework, Low level of community involvement, market penetration, Limited product development and diversification, limited financial incentives, Inadequate research and skills base, Inadequate infrastructure stock and Environmental degradation are the major constraints affecting the ecotourism growth in the IGAD region [44]. In Ethiopia, tourism has been effectively recognized as an important sector for poverty reduction. The government's strategic intent is to make Ethiopia one of the top ten destinations in Africa by 2020, while attracting low-impact high-value tourists (United Nations Development Programme [45].

\section{Conclusion and Recommendation}

The country has a wide variety of wildlife habitats ranging from alpine moor lands to lowland savannahs with extensive wetlands. The principal economic uses of wildlife are: tourism, displayed in zoo, domestication of game species, safari/trophy hunting, and game cropping. On the other hand Ethiopia's Ecotourism potential is huge and unmatched but the sector is in its infancy stage. Ecotourism of the country can be used as a way to promote community based natural resources management and livelihood diversification. Despite these use, Ethiopia's wildlife and ecotourism potential are constrained by different factors. Weak Policy, legal and regulatory framework, Low level of community involvement, Market penetration, Limited product development and diversification, Limited financial incentives, Inadequate research and skills base, Inadequate infrastructure stock and Environmental degradation are the major constraints affecting the ecotourism growth.

Based on the above review, the following recommendations were forwarded; increasing understanding the value of wildlife and wildlife habitats, and developing a successful and replicable wildlife educational model. Institutional and policy frameworks should have to be established and Policymakers should establish ecotourism monitoring and accountability programs to ensure that local communities receive appropriate amounts of revenue. Ecotourism development should involve the local communities in planning, developing and managing the activities. Ecotourism activities should not alter the traditional livelihoods of the local communities. Furthermore, the local Communities should be given opportunities at all levels of management. Increasing the awareness of local communities towards ecotourism or nature tourism is very important. There is an urgent need to have up to date wildlife policy and relevant legislation on the Conservation of the Sanctuary. This should incorporate law enforcement to take appropriate action.

\section{References}

2. WCMC (2001) Biodiversity Guide to Ethiopia. A report for the Commission of the European community, Cambridge.

3. Holden A (2003) Tourism and Environment. (3rd Edn) London: Taylor and Francis Group, Routledge, United Kingdom pp: 246-361.

4. Leykun A (2003) The Challenges of Conserving Ethiopian Wildlife: Ethiopian Wildlife and Natural History Society. Walia 21: 12-14.

5. Cater E (2007) Ecotourism in the Third World: Problems for Sustainable Tourism Development. Tourism Management pp: 14: 107-115.

6. Argaw A, Bishaw D, Dechassa L (2007) Ecology: In collaboration with the Ethiopia Public Health Training Initiative, The Carter Center, the Ethiopia Ministry of Health, and the Ethiopia Ministry of Education. Lecture note, For Health Science Students, Jimma University, Ethiopia.

7. Gurevitch T (2006) Fundamentals of ecology. (3rd Edn) Saunders, New York Pp: 532-621.

8. Diversity of Ecosystems (2014) Ethiopian institution of biodiversity, Diversity of Ecosystems, Addis Abeba, Ethiopia.

9. Tafesse KE (2008) Integrated Assessment of ecosystem services and stakeholder analysis of Abijata-Shalla Lakes National Park, Ethiopia. MSc: Thesis in Environmental Sciences, Ethiopia.

10. Gove JH, Patil GP, Swindel BF, Taillie T (2004) Ecological Diversity and Forest Management. Handbook of statistics 13:409-461.

11. Fassil K (2005) National biodiversity strategy and action plan. Msc thesis, Addis Ababa, Ethiopia.

12. Sinha C (2001) Wildlife tourism: Ageographical perspective.

13. Usher MB (2008) Wildlife conservation evaluation: attributes, criteria and values. London, New York, Chapman and Hall.

14. Yarrow G (2009) Wildlife and Wildlife Management. Fact Sheet: 36.

15. EWCA (2012) National Action Plan for the Conservation of Cheetahs and African Wild Dogs in Ethiopia, Addis Ababa, Ethiopia.

16. Beyer HL, Haydon DT, Morales JM, Frair JL, Hebblewhite M, et al. (2010) The interpretation of habitat preference metrics under use-availability designs. Philos Trans R Soc Lond B Biol Sci 365: 2245-2254.

17. Woldemedhin $Z$ (2011) The role of community conservation on quality of habitat and watershed health in Guassa Community conservation area. Msc thesis, Menz-Central Ethiopia.

18. Marino J (2003) Threatened Ethiopian wolves persist in small isolated Afro-alpine enclaves. Oryx 37: 62-71.

19. William S, Fensham RJ, Fairfax RJ, Archer SR (2005) Rainfall, land use and woody vegetation cover change in semi-arid Australian savanna. Journal of Ecology 93: 596-606.

20. Shibru T (2005) Protected areas management crises in Ethiopia. Walia 16: 17-30.

21. Hailemariam A, Tsegazeabe $H$ (2013) Knowledge and attitude of peasants towards birds in church forests in Tigray region, Northern Ethiopia. Int J Bi Co 5: 461-468.

22. Pai M, Serekebirhan T (2014) Wildlife Management in Ethiopian Universities: a Pen Move Mountain. Jbes 2:1.

23. Herlocker D (2000) Rangeland resources in eastern Africa: their ecology and development. GTZ, Nairobi, Kenya.

24. Tefera M (2011) Wildlife in Ethiopia: Endemic Large Mammals. World Journal of Zoology 6: 108-116.

25. Callinmanopolis D (2002) The Tourist Trap: Who is Getting Caught? Cultural Survival. Quarterly 8: 3-35.

26. Evangelista PH, John N, Paul S, Nicholas EY (2012) Assessing habitat quality of the mountain nyala Tragelaphus buxtoni in the Bale Mountains, Ethiopia. Current Zoology 58: 525-535.

27. Zebene A (2005) Natural Resource Curriculum development, Department of Wildlife and Fisheries Resource Management. Wondo Genet College of Forestry, Debub University.

28. Theodros A (2004) Sustainable Tourism Development. Paper presented on the tourism Symposium on Occasion of the World Tourism Day, Sheraton Addis, Ethiopia.

1. Koeman A (2008) Sustainable tourism and eco-tourism. pp: 1-7. 
Citation: Birhan M, Gebreyes G, (2015) Review on Problems, Prospects and Economic Contribution of Wildlife Management and Ecotourism in Ethiopia. J Veterinar Sci Technol 6: 257. doi:10.4172/2157-7579.1000257

Page 5 of 5

29. Almaz T (2006) Nature conservation and indigenous people approaches in conflict results. Ethiopian Wildlife Conservation Department, Addis Ababa. p: 2 .

30. Asebe RD (2012) Contesting Views on a Protected Area Conservation and Development in Ethiopia. Social Science 1: 24-46.

31. EPA (2004) The Conservation Strategy of Ethiopia. Action Plan for the Federal Policy on Environment 4: 32-53.

32. Eskedar k (2014) Wilderness safaris to invest in Ethiopia.

33. Adem G (2008) Assessment of Ecotourism Potentials for Sustainable Natural Resources Management in and Around Abijata-Shala Lakes National Park in the Central Ethiopian Rift Valley. Msc: thesis, Addis Ababa University, Ethiopia.

34. Gunn A \& Var T (2002) Tourism Planning; basics, concepts and cases (4th Edn) United Kingdom: Taylor \& Francis Group, Rutledge pp: 345-523.

35. Henze BP (2007) Ecotourism in Ethiopia: Opportunities and ideas Conference of IDR/AAU.

36. Minagawa Y, Tanaka N (2009) The application of Geographic Applications Systems to Tourism Development Planning: Case Study of Site Selection in Lombok Island, I ndonesia. Regional Development Studies 5: 139-159.
37. Ministry of Culture and Tourism (MoCT) (2014) Tourism in Ethiopia.

38. Sefrin C (2012) Ecotourism in Lake Tana region, Ethiopia- potential for the implementation of community-based ecotourism. GEographisches institutes derrheinischen friedrich-wilhelms-university boom.

39. TIES (2006) Global Ecotourism. Fact Sheet. Washington DC.

40. Ngece K (2002) "Community based ecotourism: What can the people of East Africa learn from success. Stories elsewhere?" East African ecotourism development and conservation consultants; Nairobi, Kenya.

41. Sisay A (2004) Adaba-Dodola community- based ecotourism development.

42. Weaver D (2009) The State of Contemporary Ecotourism Research. Tourism Management 28: 1168-1179.

43. Lindberg K (2001) Economic Impacts of Ecotourism. In Weaver DB (ed) the Encyclopedia of Ecotourism Wallingford: CABI, 363-377.

44. Himberg N (2006) Community-based Ecotourism as a Sustainable Development Option in the Taita Hills, Kenya. Msc thesis, University of Helsinki.

45. Eshetu A (2011) Ecotourism as a viable strategy for livelihood diversification and sustainable natural resource management in Ethiopia (from eco-development paradigm point of view). Jeswr 3: 040-052. 